\title{
THE PROPER ROLE OF THE LAWYER AS LEGAL REPRESENTATIVE OF THE CHILD
}

\author{
M. J. J. McHALE*
}

The increased recognition given to children in legal proceedings today brings into focus the special problems facing a lawyer in the role of legal representative of the child. The author outlines the three roles available to the child advocate: the traditional advocate, the neutral officer of the court, the guardian; and considers the suitability of each of these roles in the various legal proceedings in which a child may be involved, e.g. juvenile delinquency proceedings, custody proceedings, etc. The personal and professional qualifications required to be competent as a child advocate are examined and the author concludes by emphasizing that the multi-faceted role of child advocate requires the lawyer to assume new responsibilities and be willing to develop new skills.

\section{A. The Child in Legal Proceedings}

\section{INTRODUCTION}

Historically the child's status at common law has been wholly subordinate to that of his parent or guardian. His own rights have been narrowly circumscribed and have been quite fully eclipsed by the rights of his parents over him. ${ }^{1}$ Even a right so apparently fundamental as maintenance has been denied at common law. ${ }^{2}$ As concerns custody issues, parents' rights historically were based largely on consideration of the commercial value of the child as a revenue-generating property. ${ }^{3}$ The child has had essentially no voice of his own to identify or advance his own interests in legal proceedings.

In recent times, however, the rights of children have generally enjoyed increased recognition and promotion. In the interest of protecting the rights of minors in legal proceedings, the practice is now evolving whereby separate legal representation is provided for children involved in the court process. With increasing frequency lawyers are becoming involved as representatives of children in juvenile delinquency matters, child welfare matters and custody disputes. ${ }^{4}$ This move towards independent legal representation for children rests in part upon the principle that an individual is entitled to party status in a proceeding which may affect his rights. ${ }^{5}$ We recognize that the effects of a finding in a custody dispute are at least as profound for the child as they are for the parent, if not more so. ${ }^{6} \mathrm{As}$ a person who can make representations to the

- B.A., M.S.W. (U. of T.), LL.B. (U. of A.), student at law with the firm of Biamonte, Harper and Cairo, Edmonton.

1. See generally British Columbia, Fifth Report of Royal Commission on Family and Children's Law, Part III: Children's Rights. (Vancouver, 1975.)

2. Bazely v. Forder (1868) L.R. 3 Q.B. 559 at 565.

3. For a modern characterization of parental rights as a property interest see Turner v. Turner (1959) 334 P. (2d) 1011 (Cal. C.A.).

4. The scope of utilization of the child advocate is a separate but noteworthy issue. It has been suggested that the child may also require legal representation in cases of: mental hospital commitment, non-divorce custody proceedings, re: non-custodial issues in divorce litigation (such as maintenance), and in parens patriae actions to compel medical treatment or education. See J. K. Genden, "Separate Legal Representation for Children" (1976) 11 Harvard Civ. Rights Civ. Lib. Rev. 565. See also Wickens v. Wickens, infra n. 11.

5. See The Report of the Department of Justice Committee on Juvenile Delinquency: Juvenile Delinquency in Canada. (Ottawa: Queen's Printer, 1967) at 142.

6. H. Irving and B. Schlesinger, "Child Custody: Canada's Other Lottery", in The Child and the Courts (Baxter and Eberts eds.), Carswell Co. (Toronto, 1978) at 71. 
court through counsel, "as if" he were a party, the child gains rights of participation in the pursuit and determination of his own best interests.

The 1966 Woods v. Woods ${ }^{7}$ decision of Mr. Justice Manning is frequently noted as innovative in the practice of utilizing counsel to assist both the court and the child in the role of amicus curiae. ${ }^{8}$ Since Woods, the practice has been followed in Alberta on many occasions, and the amicus curiae ("friend of the court") is now commonly used in custody disputes.9 In 1976, the Alberta Institute of Law Research and Reform sponsored a study which recommended that the office of Amicus Curiae be established. ${ }^{10}$ This would allow the court discretionary appointment of counsel to represent children in all custody and other civil proceedings. The office would make recommendations to the court on the basis of investigations and reports elicited from independent mental health professionals. These reports, in conjunction with any other information which would help to establish an objective assessment of the child's best interests, could be brought into evidence. It was suggested that intervention by an amicus curiae be mandatory in cases of alleged abuse or neglect, custody and access disputes, and guardianship matters. ${ }^{11}$ Intervention in delinquency proceedings, it was suggested, would be discretionary.

As a matter of practice, there are some differences in the procedures currently followed in Edmonton and in Calgary. In Edmonton, the amicus curiae tends to be a solicitor from the Attorney General's Department. In Calgary, the courts frequently use a solicitor in private practice who has been retained by the Provincial Government to do general child welfare work. On occasion, lawyers from the Attorney General's Department in Edmonton have travelled to Calgary to represent children in Calgary courts. Historically, an amicus curiae has been appointed in a lower proportion of cases in Calgary than in Edmonton. As well, when an Edmonton court feels it requires independent assistance, the appointed amicus curiae takes responsibility for seeing that the necessary assessments are made and reports submitted. Calgary courts are more likely to bypass the amicus curiae and have pretrial reports submitted directly to the court. It is reported ${ }^{12}$ that in Calgary the amicus curiae tends to take a more active role in terms of willingness to cross-examine and make submissions on behalf of the children. The amicus curiae in Edmonton is less likely to regard it as a part of his function to act as an adversary but will more often simply confine his role to making evidence available to the court.

7. Unreported, Alberta registry 41784 (Alta. S.C. T.D.); (cited in Re Reid and Reid (1975) 11 O.R. (2d) 622 at 629). This case was relied on over 80 times in the first 5 years after the decision.

8. "The institution of amicus curiae is of long standing in Common Law procedural case law, having its origin in the inherent jurisdiction of the court to request its officers, and particularly the available lawyers to whom the court affords exclusive rights of audience, to be of aid to the court by presenting contentions of law upon identified issues". B. Dickens, "Representing the Child in the Courts", in The Child and the Courts (Baxter and Eberts eds.), Carswell Co. (Toronto, 1978) 273-298 at 278.

9. The legal basis for legal representation of children varies from province to province. See $B$. Dickens, "Representing the Child in the Courts", supra n. 8 at 280-286.

10. S. McKeown, "Representation of the Infant in Legal Proceedings-Who Speaks for the Child?", Alberta Institute of Law Research and Reform (Edmonton, 1976).

11. In current practice the categories may not be firmly set. In Wickens v. Wickens, an unreported case of the Alta. S.C.T.D. (March 13, 1978, digested at (1978) 2 All Can. Wkly. Summ. 112) Kidd J. appointed separate counsel to represent a child in a case where the issues before the court included maintenance, and whether the Respondent was in loco parentis.

12. R. Gosse and J. Payne, "Children of Divorcing Spouses-Proposals for Reform" in Studies on Divorce, Law Reform Commission of Canada (Ottawa, 1975). 


\section{B. The Child Advocate: The Rationale}

The legal rights, as well as the social and psychological well-being of a child, may be neglected when the court fails to recognize, or adequately account for the effect of its finding on a child. It is recognized that the child has at least as much at stake in a divorce as his parents do. ${ }^{13}$ However, the court may fail to protect the child when it assumes that the child's best interests will be adequately promoted by a party already represented before the court. In fact, the child's interests may not coincide with those of other parties, and as a consequence: ${ }^{14}$

Where the right or interest of a child will be directly or indirectly affected by a court proceeding, ... it is not good enough to rely upon the judge, the parents or the parent's counsel, to act as an advocate for the child...

The matter of adequate representation for the child by parties to the dispute is further complicated by the intensely emotional aspect of the kinds of litigation in which children tend to be involved. The objectivity of parties to a domestic dispute is frequently impaired..$^{15} \mathrm{~A}$ party claiming to speak for the child may have his perspective colored by private concerns. ${ }^{16}$ Emotional disorientation is almost inevitably a by-product of family conflict and dissolution, and the child too frequently becomes the scapegoat for destructive feelings within the family. ${ }^{17}$

It is typical for the spurned spouse ... to seek revenge in the form of money, or much worse, by using the children as a means of punishing or "getting even" with the other spouse. Children are always the casualties of their parents' marital battles. Parents frequently use their children to salve their own bruised egos, or they vie for their children's favor, thus forcing the children into conflicts of loyalties ....

Such circumstances clearly argue for the involvement of separate counsel who can utilize independent professionals, who can in turn identify the emotional issues and motives active beneath the legal issues of custody or maintenance. The use of independent professionals is a major component of the role of amicus curiae ${ }^{18}$, insofar as these professionals provide, in the words of Milvain, C. J. “. . . a very excellent and very helpful method of assisting a Judge" by facilitating "the intervention of a completely objective function"19. In this manner, the child's "genuine feelings and wishes" are more accurately ascertained ${ }^{20}$, and his best interests are better guaranteed.

13. H. Irving and B. Schlesinger, "Child Custody: Canada's Other Lottery", supra n. 6; and B. Schlesinger, "Divorce and Children-A Review of the Literature" (1977) 24 R.F.L. 203.

14. Law Reform Commission of Canada, Working Paper No. 1: The Family Court, (Ottawa, 1974) p. 40.

15. See P. Galligan, "Protection of Children in Family Disputes" (1973) 4 Can. Bar J. No. 2(N.S.) 10-12 at 10.

16. J. K. Genden, "Separate Legal Representation for Children", supra n. 4 at 573.

17. H. Irving and B. Schlesinger, "Child Custody: Canada's Other Lottery", supra n. 6 at 72. It is important to remember that, psychologically, divorce is a familial rather than a marital phenomenon and that divorce does not terminate the psychological existence of, or significance of, family relationships. See Westman, Cline and Kramer, "Role of Child Psychiatry in Divorce", (1970) 23 Archives of General Psychiatry 416-420.

18. "While legal professionals, such as judges and attorneys, are supposed to seek social and psychological data for child custody proceedings, the success of this mandated search will hinge upon the effective integration of behavioral scientists into the legal context." $R$. H. Woody, "Psychologists in Child Custody" in Psychology in the Legal Process (Sales ed.) Spectrum Publications Inc., New York, 1977.

19. Copithorne v. Copithorne (1976) 2 A.R. 431 at 432 (Alta. S.C.T.D.).

20. Bayda J.A., in Wakaluk v. Wakaluk (1976) 25 R.F.L. 292 at 304 (Sask. C.A.). 


\section{THE ROLE OF THE LAWYER}

Dickens notes that a variety of jurisdictions are providing, or soon will be providing, extended legal representation for children; but he adds that: ${ }^{21}$

No uniform pattern exists ... for the construction, powers or role of the office of a representative charged with promotion in court of a child's best interests. In some instances and proposals he is an officer of the court itself, reinforcing the court's parens patriae supervision or acting as standing amicus curiae, while in others he is specifically designated but established independently of the court service, appearing in court as amicus curiae or in a traditional role as an advocate of his client.

This lack of uniformity and variety of role definition as between jurisdictions has its direct parallel in the variety of roles available to the individual lawyer performing the amicus curiae function in Alberta. In very general terms the functions of the amicus curiae can be fairly well outlined. He conducts the requisite investigations and in doing so may utilize independent professionals capable of expert assistance and reliable guidance. He tenders any evidence he deems necessary, subject to right of cross examination. He makes, or facilitates the making of a recommendation to the court, and at all times he is mindful of the paramount consideration of the best interests of the child. Such directives, however, are only general and in the actual performance of these functions a variety of conflicting role alternatives confront the lawyer; and his choice of how to conduct himself may be a confusing and difficult one.

\section{A. Three Roles Available to the Child Advocate}

The lawyer representing the child appears to have three roles available to him. These roles have been described by various authors, each of whom employs his own individual terminology to refer to what appear to be parallel concepts. Dootjes ${ }^{22}$, for example, refers to three alternative "orientations" adopted by lawyers when representing children. MacDonald ${ }^{23}$ outlines three roles for lawyers in Juvenile and Family Courts, and likewise Leon ${ }^{24}$ identifies three distinct approaches to the task of representing the child. Each author's definition of these three roles amounts to a description of the lawyer's task in terms of increasing or decreasing emphasis on the elements of traditional advocacy, and in terms of various degrees of movement toward the "treatment" or "conciliatory" functions of the juvenile and family courts. A combined reading of these definitions produces the following terms for use in this paper:

1. the traditional advocate role: The lawyer in this role is characterized as adversarial in orientation. His major concerns include: protection of the client, observance of proper procedures, arguing technical questions of law, testing of evidence, representation of the child's wishes, and rigorous promotion of the child's strict legal rights.

2. the neutral, officer of the court role: The lawyer shifts his position from champion of the child's rights to intermediary between the

21. B. Dickens, "Representing the Child in the Courts", supra n. 8 at 290.

22. I. Dootjes, P. Erickson, R. Fox, "Defence Counsel in Juvenile Court: A Variety of Roles" (1972) 14 Can. J. Crim. and Corr. 132-142.

23. J. C. MacDonald, "Provisional Memorandum on the Juvenile Court of the Juvenile and Family Court of Metropolitan Toronto" (1967), Noted by Dootjes et al., supra n. 22 at 146.

24. J. S. Leon, "Recent Development in the Legal Representation of Children: Growing Concern with the Concept of Capacity", (1978) Can. J. Fam. L. 375 at 386-388. 
child and the court. $\mathrm{He}$ interprets court procedures and dispositions to the child and his family, while advising the judge on points of law. $\mathrm{He}$ is responsible for the accuracy and completeness of information put before the court for purposes of disposition. He puts the child's opinions and wishes before the court, as he does all other evidence, from a neutral position for the judge's determination without argument or comment. $\mathrm{He}$ is a legal resource person who plays a facilitative role in court proceedings.

3. the guardian role: The lawyer shifts from a neutral officer of the court position to a "helping" role aimed at promoting the "best interests" of the child, or finding the "least detrimental" disposition. He adopts the treatment philosophy of the court, not unlike a social worker, and acts in consideration of the child's needs (i.e., needs not necessarily as seen by the child but as perceived by the lawyer in his informed opinion). He submits reports and makes recommendations.

It is submitted that a major factor in the role confusion often experienced by counsel representing children is the tacit expectation that a single role should cover all aspects of their duties. The lawyer's proper role as representative of the child involves in fact a variety of roles. While the desire for a single, invariable role is understandable, the unique nature of litigation involving children does not allow exclusive adherence to any one of the above mentioned orientations if the child's best interests are to be realized. Different roles will be appropriate at different times and in different cases. Determination of the proper role in a given case is achieved only after considering the kind of proceeding, the stage of proceeding, the needs of the child represented and the capacity of the child to express his own wishes to counsel.

The three alternatives available to the lawyer will be discussed in the context of two general concerns. Firstly, the appropriateness of the traditional advocate role when representing the child will be examined. The central issue here is the extent to which the lawyer should hope to advance the child's best interests by use of strictly adversarial skills. Secondly, the question of precisely which interests the lawyer promotes will be explored. This issue arises as the lawyer moves away from the traditional advocacy model which allows him to rely more fully for his direction on his client's expressed wishes than may be the case when he adopts the neutral, officer of the court role, or the guardian role.

\section{B. The Adversary in a "Non-adversary" System}

Historically, the adversary approach to dispute settlement has been so ingrained in our legal system as to barely admit of any alternative mode of decision making. Lawyers and law students have been educated into the adversarial tradition for centuries and the influence of the adversarial approach on the thinking and behavior of lawyers is pervasive. Within this century the law has attempted to utilize other methods of settlement. This coincides with, and is part of, the movement which views certain former "legal" problems as social or "socio-legal" problems. Modern juvenile courts and family courts try to embody a new approach to the law's task of regulating certain aspects of social behavior. A child, for example, who breaks the law is characterized not as an "offender" or a "criminal" but as "one in a condition of delinquency", "a misdirected 
and misguided child . . . needing aid, encouragement, help and assistance". ${ }^{25}$

These changes came about as a consequence of doubts concerning the adequacy of the adversarial approach to the best resolution of juvenile or family problems. As one author notes: ${ }^{26}$

The adversary process has more than proven its value and adequacy in resolving disputes where evidentiary facts have probative significance, but its adequacy as a process for the resolution of family disputes has come under frequent attack.

\section{The Law Reform Commission of Canada states:27}

in general the adversary approach promotes a ritualistic and unrealistic approach to family problems.

The perceived inadequacy of the adversarial system to the best resolution of juvenile and family problems spilled over even further into a concern regarding the appropriateness of lawyers in the juvenile court system: ${ }^{28}$

... when a child appeared in juvenile court, the presence of a lawyer has until recently been considered incompatible with the objectives and procedures of these so-called "social" tribunals and has even been regarded as undesirable or as a possible impediment to the analysis of the case in question and to a proper assessment of the child's needs and rehabilitation.

Such views have certainly held some sway in shaping our contemporary Juvenile and Family Courts. As a consequence, lawyers have been left to adapt and modify their function in these courts. The modifications thus required have in some aspects been significant. Selby J. in Clarkson v. Clarkson, ${ }^{29}$ for example, commented that while the normal rules of procedure and laws of evidence apply, "matters concerning the welfare of children are not regarded in this jurisdiction as similar to ordinary litigation between the parties". He goes on to state that insofar as the child's best interests are to be a determining factor, certain traditional legal forms and formalities must give way to a less conflict-oriented method of dispute resolution. "Recognized tactics of advocacy which may be in every way right and proper are not necessarily of assistance in cases of this nature." 30

To the extent that "recognized tactics of advocacy" must be set aside, the contemporary lawyer is likely to feel confusion and uncertainty about his role. He is trained primarily, if not exclusively, in adversarial tactics and adversarial thinking and he knows better how to use the law in a conflict situation than as a conciliatory tool. To this extent, the lawyer in juvenile or family court may frequently be, to employ a colloquialism, a duck out of water.

Research seems to bear this conclusion out. Cayton found in defence lawyers practicing in juvenile court "a rather serious condition of role ambiguity". B1 Brennan and Ware found that probation officers preferred the lawyer in juvenile court who did not adhere strictly to a legal role but

25. Juvenile Delinquents Act, R.S.C. 1970 , c. J-3, s8. 3(2) and 38.

26. B. Lindsley, "Custody Procedures: Battlefield or Peace Conference", (1975) 13 Conciliation Courts Review 1.

27. Supra n. 14 at 11.

28. Civil Code Revision Office, Report on the Family Court XXVII, (Montreal, 1975) at 127.

29. (1972) 14 R.F.L. 313 (N.S.W.S.C.).

30. Id. at 315 .

31. Cayton, "Relationship of the Probation Officer and the Defence Attorney After Gault",(1970) 34(1) Federal Probation 8, cited in Dootjes et al., "Defence Counsel in Juvenile Court", supra n. 22 at 134. 
adopted a "therapeutic approach" as an adjunct to his duties.32 Such feelings would certainly be perceived by lawyers in these courts and would operate to make them feel less comfortable in their conventional roles. A Canadian study by Dootjes, Erickson and Fox found that: ${ }^{33}$

the informal structure of the juvenile court system, with its broad rehabilitative goals and non-adversary philosophy provides an ambiguous model for the lawyers working within its framework.

This study notes that not only does the lawyer experience difficulty negotiating a balance between his adversarial training and the conciliatory or co-operative procedures of the juvenile court, he must also contend with a number of differing expectations projected upon him by various individuals within the court system. Role confusion is heightened, for example, where counsel feels the particular judge expects him to act as an intermediary and advisor while the child expects the lawyers to be an advocate, i.e., "to get the child off". 34 The lawyers also saw their role vary depending on whether they were acting as private counsel or as duty counsel. If privately retained, lawyers tended to see their role more in traditional adversary terms.

The lawyers in Dootjes' study tended to handle this role confusion by adopting one of the three orientations discussed earlier in this paper. The first group conforms most closely to the traditional role of the lawyer in its championing of the client and concern with proper procedures and issues of law. The second group see themselves more as intermediaries between the judge, the child and social workers, with a duty to advise all participants on legal and quasi-legal issues. The third group see the lawyer's task as very similar to that of a social worker whose primary concern is the best interests of the child, from a social and dispositional point of view. Generally, the study found that the specific role selected by a lawyer is a function of both the particular circumstances of the case and the individual predisposition of the lawyer. A general trend was noted for the lawyer to modify his role over time, away from an adversary orientation, and toward the rehabilitation stance.

As might be expected courts and commentators have voiced a variety of preferences as between these alternative roles. One American author states that "an attorney in juvenile court should at all times be guided by what is best for the welfare of the juvenile ... attorneys who ... demand that the child's guilt be proven beyond a reasonable doubt ... . may be doing their clients a disservice". ${ }^{35}$ By contrast, another author states, "the lawyer's duty is to do everything for his client that the law permits. He violates that duty if he sacrifices the client's legal rights for what he, the lawyer, thinks is the most just result", 36 or "the Family Court is . . . not a social agency ... the suggestion found in some writings that zealous advocacy is incompatible with the objectives of the family court is without merit unless zeal of advocacy is confused with purposeless

32. Brennan and Ware, “The Probation Officer's Perception of the Attorney's Role in Juvenile Court", (1970) 16 Crime and Delinquency 172, cited in Dootjes et al., "Defence Counsel in Juvenile Court", supra n. 22 at 134.

33. Dootjes et al., "Defence Counsel in Juvenile Court", supra n. 22 at 147.

34. One study found that judges often pressure lawyers to cooperate with the court by being less adversarial. See Stapleton and Teitelbaum, In Defence of Yanter (New York, 1972).

35. Turner, Juvenile Justice (Charlottesville: The Miche Co., 1969) at 12-14.

36. Handler, "The Juvenile Court and the Adversary System: Problems of Function and Form", (1965) Wis. L. Rev. 29. 
obstructionism". ${ }^{37}$ This debate admits of no final resolution although compromise positions which see the lawyer's role vary according to the stage of proceedings and to the circumstances of the case have been suggested..$^{38}$

It is perhaps evident that some form of compromise between the extremes of the role choices available is required. The Law Reform Commission of Canada notes in reference to family courts: ${ }^{39}$

While there is a desirable de-emphasis on adversarial procedures, there is also a failure to provide adequate protection of the rights of individuals, particularly children.

This statement reflects the fact that while a fundamental shift away from the lawyer's traditional role is necessary, it is not desirable that this role should be abandoned entirely. The dilemma as to how much advocacy to retain in child ligation is expressed in the McRuer Commission Report: 40

This function (i.e., proscribing treatment) cannot be properly performed if he (the child) is surrounded by too many legalistic trappings; nevertheless, there must be some basic ones .... It is most difficult to lay down specific rules .... which would adequately protect the civil rights of those appearing before (the court) without unduly limiting the court's social function. (emphasis added)

Research conducted by Erickson ${ }^{41}$ in Toronto Metro Court on the subject of how judges and social workers perceived counsel's role in juvenile court yielded some observations which may serve as a starting point in fixing a standard for use of adversarial skills. The social workers and judges interviewed were nearly unanimous in their feelings that legal representation was required in juvenile court. However, the more adversarial aspects of this role, especially when the lawyer was there in the capacity of private defence counsel, were regarded as inconsistent with the philosophy and functioning of the court. At the same time there was felt to be room for the traditional advocacy role in cases of serious offences and not guilty pleas. As regards duty counsel, Erickson notes:42

The general need for duty counsel was affirmed, although in a diffuse and restricted role. One of his primary tasks was considered the protection of legal rights but in a manner that enhanced the social purpose of the court. As watchdog over the proceedings, duty counsel was to invoke his adversary skills only in those exceptional cases where the abuses seemed imminent.

It is suggested that these observations, insofar as they are made by personnel who are charged with the actual responsibility of making manifest the Juvenile Court's "quasi-cooperative" philosophy, broadly define viable parameters to the lawyer's role in that court. While the lawyer is valued for his over-all legal training, ${ }^{43}$ it is only occasionally that his strictly adversarial skills will, or should be, necessary. He is a "watchdog" over essentially non-adversarial proceedings whose twofold task is to facilitate the court's information gathering and dispositional functions while ensuring that court procedures remain within proper legal

37. J. Isaacs, "The Role of the Lawyer in Representing Minors in the New Family Court", (1963) 12 Buff. L. Rev. 501 at 506.

38. See J. Leon, "Recent Developments in Legal Representation of Children", supra n. 24 at 419.

39. Supra n. 14 at 15.

40. Royal Commission Inquiry Into Civil Rights (Ontario: Queen's Printer, 1968) No. 1, Vol. 2, at 555.

41. P. Erickson, "The Defence Lawyer's Role in Juvenile Court: An Empirical Investigation into Judges' and Social Workers' Points of View", (1974) 24 U. of T. Law J. 126.

42. Id. at 145 .

43. Id. at 147. See also Dyson and Dyson, "Family Courts in the United States", 9 J. of Fam. $L$. 52. 
limits. The lawyer must remain alert to such proper legal limits yet at the same time his adversarial skills must be tempered and modified so as to accommodate the court's unique mandate and to facilitate its treatment goals.

In the final analysis the actual role adopted in a given case may ultimately rest on some fairly pragmatic concerns. As noted, Dootjes found the individual predisposition of the lawyer and the circumstances of the particular case to be a very important influence on role selection. ${ }^{44}$ As well, that study indicates that the more experience counsel had in "non-advocacy" court settings, the more likely he would be to move toward a "social work orientation". The lawyer's role selection is further influenced by judges or other court personnel who adopt a highly legalistic or traditional approach. These factors combined with the lawyer's sensitivity to the court's social function will determine within which limits he chooses to employ his adversarial skills.

\section{The Central Dilemma: The Child's Wishes or the Child's Best Interests?}

A second major area of uncertainty in defining the child advocate's role involves not the issue of how he advances the child's interests, but the question of which interests he chooses to advance. The dilemma thus faced by a lawyer acting as an amicus curiae rests in deciding whether his function consists in representing the child's actual wishes or in representing what he conceives to be the child's best interests. ${ }^{45}$ In theory at least, the lawyer is not burdened by this difficulty in practice with adults, in that he defines all options, makes whatever recommendations seem clear to him and leaves the final responsibility for any choice with the client. The infant's capacity for informed choice is often limited and will vary with his age, maturity, individual level of development, and even with his circumstances. At least one U.S. Bar Association explicitly suggests that the child advocate should adhere to his own concept of what lies in the child's best interests, and act independently of the parents and the child's wishes. ${ }^{46}$ No Canadian Bar has been as unambiguous, and traditional notions of the lawyer-client relationship fail to provide the lawyer with adequate direction in the case of the child client. As Dickens notes:47

The language of the law is that the client "instructs" his lawyer, but the capacity of the child to do this is clearly conditioned by age, intelligence and other obvious factors ... Counsel's first duty is to the court and to the administration of justice rather than to his client's purposes, but if he departs from his client's preference, he is normally liable for dismissal. If he represents the child client's interests rather than the child's views, he may appear superfluous since the child welfare agencies are usually mandated to achieve this purpose ... The lawyer may not be able to counsel a child as he may an adult, moreover, since that may appear to be applying improper pressure to impose his views. . . .

Case law provides little clarification regarding instruction by a child client. Galligan J. in Re Reid and Reid ${ }^{48}$ in the Ontario High Court

44. Dootjes et al., "Defence Counsel in Juvenile Court", supra n. 22. Circumstances of the particular case may include the specific charge, the particular judge, the history and the age of the juvenile, etc.

45. This dilemma, while not foreign to the lawyer in Juvenile Court, arises more frequently in the context of Family Court.

46. Massachusetts Bar Assn. Committee on Ethics. Opinion No. 76-1, (February 25, 1976).

47. B. Dickens, "Legal Responses to Child Abuse", (1978) 1 Can. J. Fam. L. 87 at 118-119.

48. (1975) 67 D.L.R. (3d) 46 at 54; 25 R.F.L. 209; 11 O.R. (2d) 622. 
appointed the Official Guardian to "protect the interests of the child and act for them in these proceedings". This language seems indicative of an intent to have the child's interests, as they are determined by the lawyer and others, protected. However, in the same judgment, he states that representation must be "full, complete and independent ... as though they were parties". This, on the other hand, seems to imply a form of advocacy very similar to that of the traditional lawyer-adult client relationship. Guidelines for the proper determination of the lawyer's role are not forthcoming from the cases and the proper role of the lawyer representing the child remains at this time the responsibility of the individual counsel. It is suggested that the lawyer should make this determination on the basis of two general factors: the nature of the proceeding and the capacity of the child to properly and soundly instruct him.

\section{Proper Role Determination by the Kind of Proceeding}

To a certain extent the role adopted by the lawyer will be a function of the nature of the proceedings at which he represents the child. It is suggested that there is more room for the traditional advocate role in delinquency proceedings, for example, than in a custody dispute.

\section{Juvenile Delinquency Proceedings}

The need for procedural safeguards in juvenile court emerges out of the fact that the court is in fact adjudicating a "criminal offence".49 As a general rule, delinquency proceedings are to be governed mutatis mutandis by the provisions relating to summary convictions in the Criminal Code. 50 There is some divergence of opinion as to how far some provisions of the Criminal Code are applicable, ${ }^{51}$ although there is authority that due process of law is a clear prerequisite for a fair trial in juvenile courts. ${ }^{52}$ Adamson, C.J.M. stated in the Manitoba Court of Appeal 53 that s. 17 of the Juvenile Delinquents Act "does not deprive an accused of any of the safeguards which are fundamental to criminal jurisprudence". He goes on to specify that it does not take away the right to full answer and defence, the principle of inadmissibility of an involuntary confession or the right not to give evidence against oneself. The right to counsel in juvenile hearings has also been asserted, ${ }^{54}$ as has the need to establish delinquency beyond a reasonable doubt.55 The preoccupation with these procedural safeguards is understandably going to be more evident in juvenile court, where the child has a respondent status, than in other proceedings involving children; and one of the major guarantees of these safeguards will be the lawyer acting in his traditional role. ${ }^{56}$ It is submitted that there should be little argument regarding the

49. See A.G. of B.C. v. S. and A.G. of Canada (1965) 53 W.W.R. 129 at 155 (B.C.C.A.) where Bull J.A. states: "s. 3 clearly creates the new criminal offence of delinquency, . . .".

50. Juvenile Delinquents Act, R.S.C. 1970, c. J-3, s. 5 and 2.17.

51. See B. Kaliel, “Civil Rights in Juvenile Courts", (1974) 12 Alta. L. Rev. 341 at 344.

52. Disbery J. in Re Miller (1962) 37 W.W.R. 571 at 573 (Sask. Q.B.); and Wood J. in R. v. Nicholson (1950) 2 W.W.R. 308 at 311 (B.C.S.C.); and Juvenile Delinquents Act, R.S.C. 1970, c. J-3, s. 17.

53. $R$. v. Gerald $X(1958) 25$ W.W.R. 97 at 113. Adamson C.J.M in dissent. Dissent followed in part in Gerald Smith v. R. [1959] S.C.R. 638.

54. Brownridge v. The Queen [1972] S.C.R. [1972] S.C.R. 926.

55. R. v. Moore (1974) 22 C.C.C. (2d) 189 (B.C.).

56. The trend in U.S. decisions relating to juvenile proceedings is toward increased due process rights. See generally the Gault, Kent and Winship decisions at: (1967) 387 U.S. 1, 87 S.Ct. 1428; (1966) 383 U.S. 541, 86 S.Ct. 1045; and (1970) 397 U.S. 358, 90 S.Ct. 1068 respectively. 
necessity of a more adversarial posture on the part of the lawyer in juvenile proceedings, especially in light of the fact that the client will often be 12 years of age or older, and his capacity to soundly instruct a lawyer will be much greater than that of most children involved in custody or child welfare proceedings. The discussion earlier in this paper regarding the dilemma of the adversary in the "non-adversary" system defines the limits, however, which should be set on the use of adversarial tactics. The lawyer must fulfill his role as guardian of the child's legal rights while remembering that as an officer of the court his first duty is to the maintenance of the court's avowed aim, which involves striking a balance between the social and legal principles which guide the disposition of juvenile offenders. It is well recognized that the lawyer's role may change also with the stage of the proceedings. ${ }^{57}$ In juvenile matters, for example, the lawyer who adopts a traditional role during the course of the proceedings may adopt a guardian role to help guarantee the child's best interests at the dispositional stage.

\section{Custody Proceedings}

In the contested custody case, the child's legal representative will be entering a forum where two other adversarially-oriented lawyers will already be operating. Something new and different is needed. In fact, it is judicial recognition of the inadequacy of an adversarial approach to discovering the child's best interests which accounts for the child advocate's entry into the dispute in the first place. As Manning J. stated in Woods v. Woods: 58

Counsel for the disputing parents must obviously take instructions from their clients and some matters concerning the best interests of the children may be overlooked in the conflict between the parents.

It is suggested that counsel's role in the custody dispute is that of the neutral officer of the court whose mandate is to gather adequate information to better allow the judge to make a finding as to which disposition is in the child's best interests. He does not create a third party to the dispute but assists the court in making a more informed choice between the two parties already in opposition. He serves to bring objectivity to a kind of trial which often "tends to be vicious and vindictive, with each parent posturing as a paragon of virtue and painting the other as the devil reincarnate". 59 The lawyer's role is not to choose one parent and join in the "posturing and painting", but to ensure that the voice of the child is heard above the din. Of all three trial situations the custody dispute is most clearly in the middle ground as far as the lawyer's role is concerned. Consequently, the general rule expressed here-that the lawyer should adopt the neutral role in custody proceedings-may admit more often of exceptions. Where the lawyer is convinced that he sees clearly what lies in the child's best interests, he may feel compelled to slip over into the guardian role. On the other hand, where the child appears to have capacity to instruct him soundly and sensibly, the lawyer may slip in the other direction towards the more traditional advocate role.

57. For a discussion of the lawyer's responsibilities specifically at the dispositional stage of juvenile proceedings see: Treadwell, "The Lawyer in Juvenile Court Dispositional Proceedings: Advocate, Social Worker or Otherwise", 16 Juv. Ct. Judges J. 109.

58. Supra n. 7.

59. The Protection and Representation of Minors, 13 Collogue International du Droit Compare (Travaux, Edition de l'Universite d'Ottawa, 1975). 


\section{Child Welfare Proceedings}

Representing the child in child welfare proceedings may necessitate a shift away from the traditional and neutral roles towards the guardian role. The entry of lawyers into the child welfare process has been resisted historically on the grounds that counsel will "entrench the adversary system" and "divide the family the court is expected to strive to unite".60 The Alberta Child Welfare Act, R.S.A. 1970, c. 45, s. 18(4) allows, however, for the appointment of counsel in welfare proceedings to represent the child. Counsel's presence was clearly contemplated and intended by the Legislature.

In defining the "Law Guardian's" role, the Ontario Law Reform Commission has recommended that in such instances lawyers avoid the posture of "an aggressive advocate intent only on destroying the evidence of parents or of a child welfare agency" ${ }^{61}$ Leon, after reviewing some decisions in this area, concludes that the "tenor" of the judgments often promotes recognition of the child's preferences, while the "wording of the reasons for judgment" is more concerned with the child's interests. ${ }^{62}$ Leon goes on to note that legislation in other jurisdictions tends to minimize the usefulness of the traditional advocate's role, emphasize the neutral officer of the court, information gathering role, and promote primarily the guardian role. The proposed U.S. Model Termination of Parental Rights Act (Draft V, 12 April, 1976) describes the child advocate's function in such proceedings in part as conducting investigations and personal interviews with parents and/or with custodians and "when appropriate with the child to identify the child's own wishes, feelings, attachments and attitudes". Ultimately he is to "make recommendations to the court regarding plans to promote and further the best interests of the child". Especially in light of the fact that children involved in welfare proceedings will tend to be younger, and consequently less able to comprehend or formulate for themselves what is in their own best interests, it is suggested that the role adopted by the lawyer in this context will most often be that of the guardian.

In summary, the lawyer can choose from three roles, the traditional advocate, the neutral officer of the court, or the guardian. The choice of a proper role will vary in part depending on the nature of the proceeding. The traditional role, in a modified and circumscribed form, is frequently best suited to juvenile proceedings. Here the child has respondent status in a procedure governed by the provisions of the Criminal Code at a trial which must be "consistent with a due regard for the proper administration of justice". As well, such matters will involve the oldest children represented by counsel and as a rule they will be more capable of instructing him in an informed manner. In child welfare matters, the lawyer will often swing to the other extreme in his role selection. The child he represents will likely be a "neglected child" or "a child in need of protection". ${ }^{63}$ This will generally be the youngest group of children represented and therefore the least likely to have the capacity to instruct adequately at any rate. The lawyer should be the advocate for both the

60. B. Dickens, "Legal Issues in Child Abuse", Working Paper of the Center of Criminology, University of Toronto (Toronto, 1976) at 64.

61. Quoted in J. Leon, "Recent Developments in Legal Representation of Children", supra n. 24 at 412 .

62. Id. at 414 .

63. Child Welfare Act, R.S.A. 1970, c. 45, 8. 14. 
child's legal rights and social needs. He must take greater responsibility for promoting the child's personal needs insofar as neglect of these needs may be the very reason for the hearing. The custody dispute is precisely in middle ground as regards role selection. The lawyer is poised between two combatants and charged with providing the objectivity that will help the judge make a more informed choice. He does not add a new party to the dispute but acts as a vehicle for disentangling the child and his interests from the parents' conflict. It will be easy in this situation to slip into a traditional advocacy stance when the lawyer feels the child has the capacity to instruct him intelligently; and equally easy to slip into the guardian role when he feels he clearly perceives in what direction the child's best interests lie.

The greatest single variable which could operate to further influence the lawyer's choice of role, and which could operate to disrupt the scheme outlined above, is the varying capacity of the individual child to comprehend his own best interests and formulate preferences for his lawyer.

\section{E. Proper Role Determination by the Child's Capacity to Comprehend and Instruct \\ 1. The Principle}

As noted earlier, the language of the law is that the client "instructs" his lawyer. The capacity of the child to competently instruct his legal representative will vary with a number of factors including age, maturity and intelligence. However, to the extent that the child has the capacity to comprehend his own circumstances, perceive his own needs and express a sound opinion as to his own best interests, the lawyer should be compelled more toward the traditional advocate role in order to best promote the child's expressed wishes. ${ }^{64}$

The principle is a simple one: if the child is capable of making a competent decision, then he should be able to have counsel advocate that position before the court. In such a case, it would be for the court, not counsel, to determine whether that position should be honoured. If, on the other hand, a child falls short of the requisite capacity, then the lawyer ultimately must temper his case by balancing the child's preferences with his otherwise determined interests.

The question essentially is one of evaluating the child's capacity for informed instruction and the subsequent measuring of what weight to give his preferences. The issue is: can a meaningful age limit be defined at which an adequate degree of understanding can be presumed on the part of the child so as to require strict attention to his wishes?

\section{Measuring the Child's Capacity for Competent Choice}

Several branches of the law have formulated legal rules as to presumption of the capacity and non-capacity of children. The Canadian Criminal Code forbids bringing charges against a child under seven years of age and grants "something in the nature of a presumption" against criminal liability from 7 to 14 years of age. ${ }^{65}$ It is presumed that before seven years, a child is not capable of forming criminal intent (mens rea). However it is interesting to note that a psychological investigation into the accuracy of this seventh year cutoff strongly suggests that this age may

64. J. Leon, "Recent Developments in Legal Representation of Children", supra n. 24 at 385-6. 65. See R.S.C. 1970, c-34, s8. 12 and 13; and Acadia Coal Co. Ltd. v. MacNeil [1927] S.C.R. 497 at 504. 
be late. Piaget's studies, for example, indicate that capacity to form the requisite mens rea may exist in children as young as three or four years of age. 66

The age of liability for children in tort law is not nearly so specifically defined. Linden refers to the law in this area as a "tangled skein".67 While tort law clearly recognizes and protects children from liability on the basis of their diminished capacity, the point at which a child is liable has not been defined with clarity. Children of "tender age" are totally immune from tort liability. Various definitions of "tender age" exist, but Linden states: 68

The complete exemption probably does not extend beyond five years of age for, according to the Supreme Court of Canada, it was wrong to say that a child of six could not be guilty of contributory negligence.

Various standards and tests apply to the child beyond tender years. There is a recognized middle ground somewhere between five and eighteen years where children will be excused from the adult standard of care. Garrow J. indicates that the test may be subjective. ${ }^{69}$

There is no hard and fast rule as to what may in civil matters be regarded as the years of discretion. One child at ten years may have more discretion or common sense than his brother at fifteen.

The Juvenile Delinquents Act, which covers children under the age of 16 years, makes the parent or guardian liable to pay fines, damages, or costs where that parent or guardian "has conduced to the commission of the offence by neglecting to exercise due care of the child . ..".70

The Alberta Child Welfare Act provides that an order of adoption shall not be made for a child 14 years of age or over without his consent..$^{71}$ In practice, a judge may take a child seven years of age or over into chambers to satisfy himself of the child's feelings regarding the order.

Very generally, it appears that the law regards children below five years of age as lacking adequate awareness or understanding of their environment to make fully responsible judgments. Over 14 years of age, there is a strong inclination to regard the child as more competent, responsible and capable of reasonable judgment. Standards, however, are either officially or unofficially subjective and there is considerable overlap depending on the area of law and the nature and personality of the individual child. Children between five and fourteen years of age are in a grey area and the issue of their capacity is evaluated quite subjectively at law.

The medical, social and psychological sciences can contribute to, but cannot resolve, the issue of precise determination of the age of capacity. Leon cites studies by Bersoff which indicate that: ${ }^{72}$

The behavioral sciences have not provided observable and verifiable criteria on which determination of a specific child's capacity to choose between parents in a custody dispute might be based.

66. Keasey and Sales, "Children's Conception of Intentionality and the Criminal Law" in Psychology in the Legal Process (B. Sales ed.) Spectrum Publications Inc. (New York, 1977) at 139.

67. A. Linden, Canadian Tort Law (Toronto: Butterworths, 1977) at 100.

68. Id. at 101.

69. Tabbs v. Grand Trunk Ry. (1904) 8 O.L.R. 203 at 208 (Ont. C.A.).

70. R.S.C. 1970 , c. J-3, s. 22.

71. R.S.A. 1970 , c. 45 , s. 55.

72. J. Leon, "Recent Developments in Legal Representation of Children", supra n. 24 at 422. 
In regard to capacity and comprehension in the litigation process generally, Catton notes: ${ }^{73}$

... no research has been undertaken to establish in a scientific manner the age below which most children are unable to understand the nature and consequences of legal proceedings and are thus capable of meaningful participation. Therefore, no meaningful age line can presently be drawn below which children should be presumed incapable of participating.

As these two quotations indicate, the behavioral sciences are saying that no formula can be provided for measurement of the child's capacity for meaningful participation, but that such participation may be possible at a very youthful age. It is suggested that in each case it will be a matter of counsel ascertaining the individual child's capacity for competent choice in the circumstances, and where that choice is reasonably informed, he should represent it to the best of his ability. Several points, however, must be noted. The lawyer should not evaluate the soundness of the child's choice only by its conformity to his own views. This is not to say that the lawyer's feelings will not be a guide in his evaluation. The judgments of other independent professionals involved in evaluating the child's circumstances, needs and wishes will be invaluable to the lawyer in this regard. As well, the lawyer must not equate the child's ability to communicate his wishes as a measure of either the existence of, or soundness of, those wishes. The child's ability to communicate will at least in part be a function of the lawyer's ability to facilitate the child's open consideration and discussion of his feelings. The child may be intimidated by the authority of the lawyer and the strangeness of the circumstances. As well: ${ }^{74}$

The child's lack of understanding may stem mainly from poorly defined procedures or from insufficient knowledge of what to expect rather than from inherent deficiencies in his capacity to appreciate the legal process.

The guidelines available to the lawyer in assessing the child's capacity tend to be rather rough. A review of the literature on child development and behavior which will assist the lawyer in this task is beyond the scope of this paper, but some self-education for the child advocate in this area is strongly recommended. ${ }^{75}$ This is not to suggest that self-education alone is a fully adequate response to the lawyer's responsibilities in this area. Law schools and Bar Associations must ultimately assist in providing the training and information lawyers require to properly deal with the child client.

As indicated, the role adopted by the lawyer must to a certain extent be a function of the child's capacity to capably instruct him. The admitted difficulty of ascertaining this capacity is no argument for its irrelevance. The task is much clearer when the child is under five or six, or over thirteen or fourteen years of age. At these ages the guardian role (before six years) and the traditional advocate role (after 13 years) will often be most appropriate. Where a child between six and thirteen years evidences capacity for sound choice, his express wishes should be promoted by the lawyer in his traditional role. In all cases, the lawyer, together with other

73. K. Catton, "Children in the Courts: A Selected Empirical Review", (1978) 1 Can. J. Fam. L. 329 at 344.

74. Id. at 345 .

75. J. Leon, "Recent Developments in Legal Representation of Children", supra n. 24 at 421.432 reviews some scientific literature on capacity. See also M. Lewis, Clinical Aspects of Child Development, Lea and Febiger Pub. (Philadelphia, 1971). 
professionals, must carefully and cautiously assess the child's capacity for competent choice. Such competence may be roughly assessed by determining whether the child:76

... is able to appreciate the nature and purpose of the proceeding, the alternatives available to the court, the risks to him if he is permitted to remain at home, and ... appears to possess sufficient maturity to weigh these factors with a reasonable degree of objectivity.

In cases of any significant doubt as to capacity or uncertainty as to best interests, the lawyer should adopt the neutral role, making it his task to put all relevant information before the judge, who will make the final decision.

In practice the amount of weight given to the child's expressed interests by the judge is most likely a function of his assessment of the child's capacity for informed choice. ${ }^{77}$ Bayda J.A., in his dissenting judgment in Wakaluk v. Wakaluk, notes that "whether to allow a child to express his own wishes in a custody proceeding is a matter for the discretion of the trial judge". Regarding the weight to attach to such wishes he cautions: ${ }^{78}$

It must be remembered that the purpose of obtaining those wishes is not to give effect to them but to put the judge in a better position to decide what is in the best interests of the child.

In the Ontario High Court case of Rowe v. Rowe ${ }^{79}$ Reid J. found contrary to the children's expressed wishes when he felt that such wishes were not in the child's best interests. Galligan, J. in $H$. v. $H .,^{80}$ while making an order consistent with the children's desires, stated that the children's wishes are only one factor to be considered in a custody decision.

The child's wishes, while not controlling, must be given significant weight.81 The younger the child the less weight his wishes will carry at law, and where the child is very young, his wishes cannot be a factor. ${ }^{82} \mathrm{~A}$ Supreme Court of Canada case ${ }^{83}$ warns against the possibility of undue influence of the parent with custody over the child's preferences, and a Nova Scotia Supreme Court decision ${ }^{84}$ found the child's expressed wishes more "impressive" when they were evidently not the result of coaching by one parent. An Ontario study ${ }^{85}$ was unable to show any agreement between judges as to when the child's wishes should be considered and as to how much weight they should be given. The Law Reform Commission of Canada has suggested that the child's wishes be weighed as a factor

76. J. Leon, "Recent Developments in Legal Representation of Children", supra n. 24 at 411 quoting J. Dick, "The Role of Counsel in Neglect and Dependency Proceedings" in Juvenile Court in Transition, 49th Annual Legal Aid and Defender Conference, 5 November 1971 (Denver, Colo.).

77. See Marshall v. Fournelli [1927] S.C.R. 48 at 49; (1927) 2 D.L.R. 173 at 174; and McDonald J. in Currie v. Currie (1975) 18 R.F.L. 47 at 52 (Alta. S.C. T.D.).

78. Supra n. 20 at 304-5.

79. (1976) 26 R.F.L. 91.

80. (1976) 13 O.R. (2d) 371 at 372; 71 D.L.R. (3d) 161 at 162; 29 R.F.L. 200 at 201 (Ont. H.C.).

81. Shapiro v. Shapiro (1973) 33 D.L.R. (3d) 764 (B.C.C.A.); Re Kuehn (1976) 29 R.F.L. 72 (B.C.S.C.).

82. Smith v. Reid (1914) 6 W.W.R. 486 at 489 (Sask. S.C.).

83. MacDonald v. MacDonald [1976] 2 S.C.R. 259; 62 D.L.R. (3d) 301; 21 R.F.L. 42. See also Cross J. in $\operatorname{Re}$ S. (1967) 1 W.L.R. 396; (1967) 1 All E.R. 202 at 210.

84. H. v. H. (1976) 22 N.S.R. (2nd) 67 (N.S.S.C.T.D.).

85. A. J. Bradbrook, "An Empirical Study of the Attitudes of the Judges of the Supreme Court of Ontario Regarding the Workings of the Present Child Custody Adjudication Laws", (1971) 49 Can. Bar Rev. 557. 
[VOL. XVIII, NO. 2

relating to his best interests but measured in the context of the particular child's age and level of maturity. ${ }^{86}$

\section{$F$. Unchanging Responsibilities of the Child's Lawyer}

It has been suggested that there is no single role to be adopted by the lawyer representing the child, but that the particular role employed will be a function of the nature and the stage of the proceedings, and the capacity of the individual child. Yet certain aspects of the lawyer's role will not change from one proceeding, or from one child, to the next.

Obviously the lawyer must make himself fully aware of all facts and all legal issues relevant to the case. He should make an effort to establish a relationship with the child sufficient, at a bare minimum, for the child to have some understanding of whatever role the lawyer intends to enact for him. The lawyer is in the best position to interpret the court to the child and his family. As well, the lawyer should be familiar with nonlegal resources in the community. The child advocate should always be prepared to involve other independent professionals for the purpose of assessment and recommendation regarding the child's best interests. These professionals can also be of assistance to the lawyer in carrying out another responsibility-efforts toward negotiation and settlement. ${ }^{87}$

An important function of counsel representing the child is negotiation, to avoid litigation. Social workers and child psychologists can work with counsel representing the child to negotiate a settlement and avoid a court contest.

While the lawyer must always be watchful to involve these other professionals, he must at the same time continually scrutinize and evaluate all assessments and recommendations they make. The lawyer must search for bias and inadequacy in reports submitted and make his own independent evaluation of dispositions suggested.88 While the role of independent professionals in this regard may often be determinative, the lawyer should remain continually alert to opportunities to offer innovative solutions to the child's problems. On perceiving any defect of assessment or recommendation, he must act so as to protect the child's best interests. The lawyer must be alert to the effect of the litigation process on his child client and act so as to minimize the distress litigation may cause the child. In all litigation involving children, and particularly in custody disputes, the lawyer should act so as to ensure the speediest possible resolution and conclusion of the case. ${ }^{89} \mathrm{As}$ well, no matter what kind of proceeding he participates in or what particular role he adopts, he remains an officer of the court charged with maintenance of fairness, impartiality, proper procedure and protection of individual rights.

Finally it should be stressed that the lawyer's loyalty must be exclusively to the interests of his child client. The lawyer may find himself in a dilemma when he is hired by a parent to represent a parent and a child, and he subsequently forms the opinion that the interests of his two clients are not compatible. In the case of the amicus curiae in a custody dispute, however, this dilemma does not arise insofar as one of counsel's primary functions is to provide the court with ". . . professional

86. Law Reform Commission of Canada: Report on Family Law (Ottawa, 1976) at 55 and 66.

87. T. Gove, "Counsel Representing Children in Custody and Access Cases", (1978) 36 The Advocate 119 at 120.

88. See G. Johnston, "The Function of Counsel in Juvenile Court", (1969) 7 Osgoode Hall L.J. 119 at 206-207 for a full discussion of the lawyer's role as a check on other professionals.

89. The importance of rapid resolution of custody disputes is stressed by Goldstein et al., Beyond the Best Interests of the Child, supra n. 8 at 31-52. 
assistance that has not been hired by either side to view the situation".90 The lawyer's position is perhaps less clear when he is hired by a parent to represent a child in Juvenile Court, and he receives conflicting instructions from parent and child. Of the lawyers surveyed by Dootjes ${ }^{91}$ the majority stated that in the case of such conflict they would support the child, although more lawyers indicated they would feel free to support the child if acting as duty counsel than if they were hired as private counsel. Those who did not feel they could support the child suggested they would seek compromise positions as well as direction from the judge. On the specific issue of the right to waive counsel, Chapman suggests that the general consensus amongst commentators is that only the child should be able to exercise this right.92 $\mathrm{He}$ goes on to note that: ${ }^{93}$

The parents do not have to bear the court's disposition, or the resultant stigma of being adjudged a "juvenile delinquent", so they therefore should not also affect the child's right to counsel.

The Report of the Committee on the Representation of Children in the Provincial Court (Family Division)94 states that ". . . a child is obviously a party to proceedings under the Juvenile Delinquents Act. As a party to proceedings the child had the right to instruct counsel . . ." Such right attends his defendant status. To the extent that the child is thus characterized as a party he comes within s.2(c)(ii) of the Canadian Bill of Rights ${ }^{95}$ which guarantees him the right to retain and instruct counsel. Thus in a case of conflicting instructions from parent and child in Juvenile Court, counsel's obligation should be to support the child.

\section{AMICUS CURIAE: PERSONAL AND PROFESSIONAL QUALIFICATIONS}

Insofar as the function of legal representation of the child invokes new conceptions of the lawyer's duties and roles, as well as different relationships with the client and with the court, it is suggested that certain personal qualifications and characteristics may serve the child advocate well.

It is perhaps too obvious to say that the consequences of juvenile or custody proceedings for the child involved are potentially enormous. The proceedings themselves are often confusing and upsetting for the child and the events which precede and follow litigation can be severely traumatic. ${ }^{96}$ The child who is the object of a custody dispute for example will be under considerable stress as he tries to cope with the effects of his parents' separation. Referring to pre-school children, McDermott states: ${ }^{97}$

To the majority of children of this age, divorce has a significant impact and represents a major crisis. There is often an initial period of shock and acute depressive reactions.

A significant proportion of children of separated parents show evidence of

90. Copithorne v. Copithorne, supra n. 19 at 431-2.

91. Dootjes et al., "Defence Counsel in Juvenile Court", supra n. 22 at 145.

92. P. B. Chapman, "The Lawyer in Juvenile Court: 'A Gulliver Among Lilliputians' ", (1971) 10 Western Ont. L.R. 88 at 98 .

93. Id. at 98 .

94. Ontario Ministry of the Attorney General, (June, 1977) at 21.

95. 8-9 Elizabeth II, c. 44.

96. See K. Catton, "Children in the Courts", supra n. 72 at 344-345.

97. J. F. McDermott, "Parental Divorce in Early Childhood", (1968) 124 Am. J. Psych. 1431 at 1434. 
long-term chronic maladjustment, characterized by depression, low selfesteem and frequent school and peer difficulties. ${ }^{98}$ This point is stressed only to make it adequately clear that the best interests of the child involve considerations well beyond the scope of the law alone. Genden notes that "a child may have less need for a litigation specialist than for a lawyer who has competence and familiarity with non-legal resources". ${ }^{99}$ Steinberg makes a similar point in slightly stronger terms when he states that: 100

Matters involving human welfare go beyond the expertise of those skilled only in the profession of law. The adequate representation of children in these areas can only be properly carried out by either a team of lawyers and social scientists, or by those persons uniquely skilled in both professions.

It is suggested that the child advocate must possess not only the legal skills adequate to the child's situation, but he must also possess social and inter-personal skills adequate to allow him to establish a substantial human relationship with the child client. To fulfill his legal function he must be able to engage his client in such a manner as to ascertain the child's true feelings, wishes and concerns. To further the court's social function he must understand the child well enough to understand the child's best interests. This goes beyond mere liaison with mental health professionals. It demands some comprehension of child psychology, social development and the nature of inter-personal dynamics as well as the ability to employ this knowledge in a comfortable relationship with the child. 101

In order to deal effectively with his client the child advocate requires very special personal abilities. He or she must be able to understand how children think and express themselves. The advocate should know how to interview the young client, how to listen, and how to understand. He or she must also be able to perceive when the child is repressing matters of major concern.

The failure of the lawyer to achieve this both hinders the child's wellbeing and frustrates the court's purpose. Erickson notes from her discussion with social workers and probation officers in juvenile courts that: 102

A frequently volunteered view was that only lawyers with special training in law and philosophy of the juvenile court, and familiarity with its resources should appear there. The lack of preparation of most new inexperienced counsel was a recurring complaint in the interviews. The nations' law schools may wish to consider whether practical preparation for this particular forum is part of their social and professional obligation.

Traditionally, law has been a highly instrumental and technical profession characterized by formality and propriety in the carrying out of its functions. The precise, even mechanical nature of legal work has presumably tended to attract individuals who thrive on well-ordered, predictable and emotionally cool work. This assumption is supported by the verifiable observation that personality characteristics play a significant role in occupational choice. ${ }^{103}$ As well, assertiveness, even aggressiveness, are not altogether undesirable or uncommon traits in a

98. H. Irving and B. Schlesinger, "Child Custody: Canada's Other Lottery", supra n. 6 at 77.

99. J. K. Genden, "Separate Legal Representation for Children", supra n. 4 at 589.

100. D. Steinberg, “Children's Rights", (1974) 22 Chitty's L.J. 238 at 242.

101. J. K. Genden, "Separate Legal Representation for Children", supra n. 4 at 589-590.

102. P. Erickson, "The Defence Lawyer's Role in Juvenile Court", supra n. 41 at 146.

103. See A. Roe, "Personality Structure and Occupational Behavior" in Man in a World of Work (Henry Baron ed.) 1964 at 199-202. 
professional system traditionally based on adversarial contests between parties with competing rights. ${ }^{104}$ The affectively-loaded and emotionally volatile nature of litigation involving the family, together with the conciliatory and informal nature of the family court process, stands rather in contrast to the well ordered, instrumental, competitive kinds of work which lawyers traditionally prefer. This distinction is not without consequence. The avoidance of the area of family law amongst members of the private bar is notorious. It is therefore suggested that in part, the "confusion" lawyers are experiencing over their proper role in family and juvenile courts might more accurately be characterized as a "discomfort" with the alternative roles they are expected to fulfill. The new roles demand not only a different form of activity, but a qualitatively different kind of involvement with the client. As Johnston observes: ${ }^{105}$

The role of counsellor to the child is the primary and most important role which a lawyer can play in the juvenile court process. This role is demanding and time consuming. It calls not only for legal expertise but a thorough knowledge of the diagnostic and therapeutic techniques developed and used by the social services. . . . In performing this function, the lawyer must become so closely identified with him that the child not only feels that he has a confidant, but also appreciates the fact that he has established a relationship with someone in the whole process who is guided by the child's interpretation of the circumstances.

Lawyers are cautious, if not distinctly reticent, about this kind of relationship. A tangible manifestation of the lawyer's uncertainty and scepticism about this kind of role is apparent in the perennial phenomenon of lawyer-social worker antagonism. ${ }^{106}$ Yet the guardian role, and to a lesser extent the neutral officer of the court role, do involve a closer identification and involvement with the child client than has been the norm in traditional practice with the adult client. Legal education does little to diminish the lawyer's lack of familiarity with the social work function and lawyers remain cautious about adopting a "quasi-social work" role. This guarded attitude certainly constitutes an element of the lawyer's confusion as to his proper role in representing the child.

\section{CONCLUSION}

Irving and Bohm, in discussing the consequences of legal dissolution of the family, note that:107

... a lawyer, a counsellor and a client, while usually occupying distinctly different statuses, are simultaneously likely to share a number of roles in common ... (ex: helper, "helpee", advocate). . . . Conflict between the members of this triad may result when members are seen as usurping the domain of others.

The creation of non-adversarial courts with "conciliatory" as opposed to "contest" procedural orientations has demanded corresponding changes in the roles played by lawyers as representatives of children in these courts. It has been suggested that some of the confusion in the profession as to the nature of their role is a consequence of the erroneous assumption that there will be only one, unchanging role. In fact, the lawyer's proper role will vary depending on the nature of the proceedings, the stage of the

104. See A. Watson, "The Quest for Professional Competence: Psychological Aspects of Legal Education", (1968) 37 U. of Cincinnati L. Rev. 93.

105. G. Johnston, "The Function of Counsel in Juvenile Court", supra n. 88 at 205.

106. It is recognized that both professions play a role in the genesis and maintenance of this interprofessional discord.

107. H. Irving and P. Bohm, "A Social Science Approach to Family Dispute Resolution", (1978) 1 Can. J. Fam. L. 39 at 45. 
proceedings, the best interests of the individual child and the capacity of the individual child for accurate appreciation of his situation and his alternatives. Three general roles exist for the lawyer representing the child, each with varying degrees of emphasis on the traditional adversarial and advocacy skills. In many situations, the role demanded of the lawyer will be quite unlike that which he has traditionally been educated to perform. It has been suggested that the lawyer's unfamiliarity and discomfort with the "quasi-social worker" aspects of (especially) the guardian role further contribute to his "confusion" over the proper role to adopt. As Irving and Bohm note above however, the present system invites, even presumes, a certain overlap of these roles which may result in confusion for all professionals involved. Yet this overlap of roles is to an extent unavoidable. Irving and Bohm properly observe that "The human ramifications of divorce are too complex to be dealt with by a single profession."108 The limitations of the power of the law to cure social problems on the scale which they currently exist is recognized. As Goldstein et al. observe:109

Too frequently there is attributed to law and its agents a magical power-a power to do what is beyond its means. . . . The law, so far as specific individual relationships are concerned, is a relatively crude instrument. It may be able to destroy human relationships; but it does not have the power to compel them to develop.

These limitations demand that the law resort to the utilization of new and alternative resources. This also means that the individual lawyer must resort to the utilization of new and alternative resources to best carry out his responsibility as the child's legal representative. The lawyer is understandably confused as to precisely what this means or what it demands of him. In practice, it means a move towards skills and duties new to his profession.110

\footnotetext{
... the development of a valid concept of child law advocacy requires meaningful interaction between the legal and social work professions . . . it is the joint function of both the legal and social work professions to define and to strike a proper balance of the legal and social rights of children both within the family and before the courts in order to make our concept of child advocacy work.
}

This means that to the extent which the lawyer sheds his traditional role in family and juvenile courts, he must assume new responsibilities for the social and psychological welfare of the child. This will require that the lawyer educate himself, and develop some proficiency, in areas left to date more or less completely to professionals in the behavioral sciences. Given this proficiency, the lawyer would undoubtedly assume his multi-faceted role as guardian of both the child's legal rights and social interests with greatly increased confidence and certainty.

108. H. Irving and Irving, "Conciliation Counselling in Divorce Litigation", (1974) 10 R.F.L. 256 at 265 .

109. Goldstein, Freud, Solnit, Beyond the Best Interests of the Child (London, 1973) Collier MaciMillan at $49-50$.

110. D. Steinberg, "Children's Rights", supra n. 1 at 238-239. 